\title{
Bioplastic Biodegradation Based on Ganyong Umbi States with Addition of Sorbitol and CMC (Carboxy Methil Cellulose) In Soil Media
}

\author{
Lukman Ma'arif, Ulia Fitrass, Endaruji Sedyadi* \\ Chemistry Department, Faculty of Science and Technology, Sunan Kalijaga Yogyakarta \\ Email*: endaruji@yahoo.com
}

\begin{abstract}
Bioplastics made using the basic ingredients of canna tuber starch with sorbitol plasticizer and the addition of CMC variations have been carried out. This study aims to understand the effect of adding CMC to the mechanical properties and biodegradability of bioplastics in soil media. This research was carried out with 4 stages of work namely, extraction of starch from canna tubers, synthesis of bioplastic manufacturing using the blending method, testing mechanical properties in the form of thickness, tensile strength, elongation, and young modulus. Characteristics of functional groups have been tested using FTIR and bioplastic biodegradability testing has been carried out on soil media for 21 days by looking at weight loss from bioplastics. The variation of adding CMC used is $0 ; 0.25 ; 0.5 ; 0.75$; $1 ; 1.25 ; 1.5$ and 2 grams. The best mechanical properties are produced with thickness of $0.0795 \mathrm{~mm}$, tensile strength of $27.53 \mathrm{MPa}$, elongation of $3.018 \%$ and young modulus of $885.66 \mathrm{MPa}$. The results of bioplastic biodegradation testing on soil media for 21 days showed that bioplastics made were biodegradable. Reduction of bioplastic mass in soil media by $86,032 \%$.
\end{abstract}

Keywords: Bioplastics, Canna Bulb Starch, CMC, Mechanical Properties, Biodegradation.

\section{INTRODUCTION}

Consumption of the use of plastics will continue to grow along with the increasing needs of the community and industrial production of plastics. As a result, the more people who use plastic, the greater the pollution of plastic waste in the environment. Plastics that are commonly used by the public are petroleum-based plastics that have non-renewable and non-biodegradable properties because they have a very complex molecular structure that makes it difficult to be degraded by microorganisms (Darni et al, 2010).

One way to overcome the problem of plastic waste is to make plastics that are based on natural polymers and can be degraded by soil microorganisms or commonly called biodegradable bioplastics (Hasanah et al, 2016).

Bioplastics are plastic that can be renewed and degraded quickly. Materials that can be used as bioplastic raw materials can be grouped into two groups. The first group is biopolymers which are directly extracted from biomass consisting of polysaccharides (such as starch, cellulose, chitin, chitosan, fiber, and gums), proteins and lipids. The second group is biopolymers that are produced directly by genetically modified natural organisms such as microbial polyester, bacterial cellulose and polyester synthesized from biologically derived monomers (Ghanbarzadeh et al., 2010)

The raw material used for the manufacture of biodegradable bioplastics in this study is starch. Starch is a polysaccharide that contains amylose and amylopectin which can be used in making biodegradable plastics (Anas, 2012). Sources of starch in Indonesia are very numerous, one of which comes from canna tuber (Canna edullis Kerr) which has a starch content of $93.30 \%$ (Harmayani et al., 2011). High levels of carbohydrates in canna have excellent prospects for development into biodegradable plastics (Anas, 2012). Biodegradable bioplastics derived from starch have the disadvantage that they tend to be rigid and brittle so plasticizers need to be added (Hidayat et al., 2013). The addition of plasticizer can reduce intermolecular strength, increase the mobility and flexibility of the plastic so that it can overcome the fragile nature of bioplastics (Darni et al., 2010). One type of plasticizer that is often used is sorbitol. The use of sorbitol as a plasticizer is known to be more effective compared to glycerol because it is reducing oxygen permeability, has high stability and is non-toxic (Hidayati, et al., 2015).

Fillers such as CMC which are cellulose derivatives are also needed in making plastics to increase the tensile strength and improve the surface structure of bioplastics (Hidayat et al, 2013). The interaction between hydroxyl groups of starch with hydroxyl and carboxyl groups of CMC causes hydrogen bonds between starch molecules and $\mathrm{CMC}$ to increase, thereby increasing the tensile strength of bioplastics which is increasing (Elean, 2018). Selection of canna starch, sorbitol plasticizer, and CMC is expected to be an alternative solution for making environmentally friendly bioplastics.

One important trait that must be possessed by bioplastics is their ability to be degraded in the environment. According to (Khalistyawati, 2016), the method often used in biodegradation testing by a microorganism is the soil burial test method, and the mixed microbal batch method, where the sample is 
degraded by a group of different microbial species and inoculated in liquid media with the test specimens affected by the type microbes, $\mathrm{pH}$, temperature and humidity of the air. Based on the above background, it is important to conduct research on bioplastic biodegradation based on canna starch with the addition of sorbitol and CMC variations in soil media to determine the degree of degradation of bioplastics in the two degradation media.

\section{RESEARCH METHODS}

\section{Research Tools and Materials}

Non-electronic devices used include a set of glassware, chopsticks, tweezers, thermometers, magnetic stirrers, bioplastic molds (mica), filter paper, soil testers and biodegradation media tubes. Electronic devices that will be used include blenders, hot plates, ovens, and analytical tools such as analytical balances, FTIR spectrophotometers, and a set of tensile and elongation strength gauges. While the ingredients used are canna tuber starch, CMC, sorbitol, glacial acetic acid and distilled water.

\section{Research Work Procedure}

The work procedures carried out in this study include four stages, namely making starch from canna tubers, making biodegradable plastics, bioplastic characterization tests, and biodegradation tests. The work procedures are described as follows: Making Canna Bulbs StarchCanna bulbs are selected which are still fresh and then peeled their brown skin, then washed and cut into small pieces. Cut canna tubers then add distilled water and blend until it is completely smooth to produce pulp. The resulting pulp is then separated between pulp and starch by filtering gradually using a sieve. Furthermore, it was deposited for 24 hours to form a precipitate. The precipitate is then dried in an oven at $60^{\circ} \mathrm{C}$ for 8 hours. Canna tuber starch produced was then analyzed for functional groups using FTIR. Manufacture of Biodegradable Bioplastics Canna bulb as much as 3.0 grams and dissolved with $100 \mathrm{ml}$ of distilled water and then stirred using a stirrer. Each solution was added by CMC with a variation of $0 ; 0.25 ; 0.5 ; 0.75 ; 1,0 ; 1.25$; 1,5 ; and 2.0 grams, then added 1.1175 grams of sorbitol and $1.5 \mathrm{ml}$ of glacial acetic acid and then heated at $80^{\circ}$ $\mathrm{C}$ until homogeneous for 25 minutes. Bioplastic solutions that have been thoroughly mixed are carefully poured into the mold. Then the printed solution is dried in an oven, then cooled to room temperature. Bioplastics that have been formed are then released for further analysis and testing. Testing of Physical Mechanical Properties of Bioplastics Bioplastic canna root starch with additional CMC which has been formed subsequently through a series of tests in the form of thickness measurement, tensile strength test, elongation and young modulus.

\section{Biodegradation Test}

Biodegradation test was carried out on two degradation media namely soil. Sample preparation is done by cutting bioplastics with a size of $4 \times 4 \mathrm{~cm}$ then weighed using an analytical balance. Biodegradation testing is done by burying bioplastic samples in the soil as deep as $5 \mathrm{~cm}$ for 21 days. Measurement of mass reduction from bioplastics is done once every 2 days by means of being taken from the media then cleaned using distilled water and then dried in an oven with a drying temperature of $50^{\circ} \mathrm{C}$ for 1 hour then weighing on the analytical balance. According to Chinaglia (2018), the percent biodegradation of the sample can be determined from the mass of the sample lost by the equation:

$\%$ Biodegradation $=\left(a_{1}-a_{2}\right) / a_{1} \times 100 \%$.

Note:

$\mathrm{a}_{1} \quad=$ massbefore testing (grams)

$\mathrm{a}_{2}=$ mass after testing (grams).

\section{RESULT AND DISCUSSION}

\section{Making Canna Bulbs Starch}

Canna root starch extraction is done simply using distilled water as the solvent. The method used to separate starch from canna tubers is the solid-liquid extraction method. Solid-liquid extraction is the process of separating a solute contained in a solid by contacting the solid with a solvent. The extraction process begins by cutting the canister tubers to a small size, this is to facilitate the refinement process in making canna tuber pulp using a blender. Canna tuber pulp is produced by smoothing the tubers in a blender then adding distilled water. Aquades are used because of the nature of starch granules that are not soluble in water at room temperature, so that starch can be deposited and separated (Kusnandar, 2010). The starch extract solution formed is then allowed to stand for the precipitation process. Filtering is then carried out to take canna tuber starch. The starch obtained is then heated in an oven. The purpose of drying starch is to reduce the water content of starch. The shelf life of starch is expected to be longer because the growth of bacteria and mold will be inhibited if the water content in starch is low. The dried starch is then sieved so that the size of the starch is uniform. Starch obtained from the extraction process is brownish-white with a smooth and abrasive texture. Pure starch produced as much as 148 grams of canna tuber as much as 2000 grams with a yield of as much as $7.4 \%$. The starch was then characterized by its functional group using the FTIR instrument and ready to be used as a bioplastic material.

Canna bulb starch obtained from the extraction of liquid solid is then characterized by its functional group 
using FTIR spectrophotometer at wave numbers 400 $4000 \mathrm{~cm}^{\wedge}(-1)$. Identification of canna starch functional groups using FTIR spectrophotometer aims to prove that the synthesized canna starch has been formed. The results of the functional group analysis of canna tuber starch are presented in Figure 1. The spectrum of FTIR analysis results from canna tuber starch showed a widening absorption at wave number $3448.72 \mathrm{~cm}^{\wedge}(-1)$ which is an $\mathrm{OH}$ group. The uptake in the area 1373.32 $\mathrm{cm}^{\wedge}(-1)$ is a CH_2 group. The C-O group is seen in the absorption area of $1165 \mathrm{~cm}^{\wedge}(-1)$. Wave number $2924.09 \mathrm{~cm}^{\wedge}(-1)$ is a C-H group, besides that there is an absorption in the area of $1651.07 \mathrm{~cm}^{\wedge}(-1)$ which is the absorption of the $\mathrm{C}=\mathrm{O}$ group. Based on the above data it can be concluded that the synthesized starch is canna tuber starch because it has a functional group that is in accordance with the structure of the starch components, namely $\mathrm{OH}, \mathrm{C}-\mathrm{H}$ and $\mathrm{C}-\mathrm{O}$.

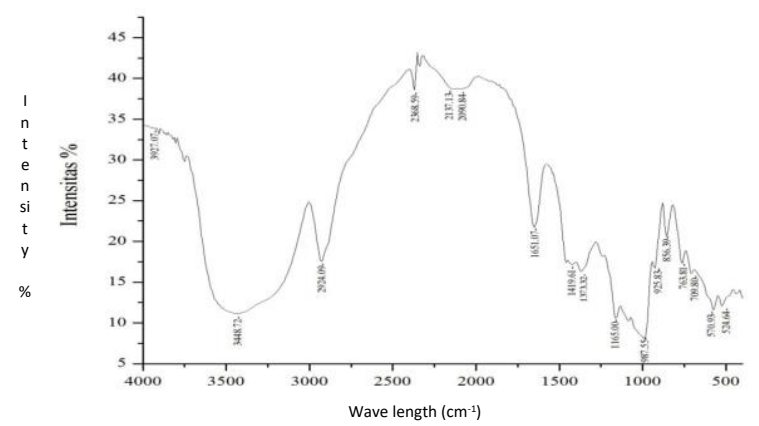

Figure 1. Results of the tunctional group analysis or canna tuber starch.

\section{Making Bioplastic}

The making of bioplastics in this research was carried out using the blending method, which is a method of mixing two or more ingredients into one. The advantages of this method are that the material used is relatively small, the time required is relatively short and the cost is much cheaper.

Bioplastics are made by mixing canna starch, sorbitol, glacial acetic acid and CMC variations. Canna starch is first dissolved using distilled water for 15 minutes in order to make the canna starch and aquades homogeneous, then added sorbitol, CMC and glacial acetic acid. The addition of CMC serves as a filler that can increase the tensile strength of bioplastics. According to Hardjono (2016), states that bioplastics with the addition of CMC will increase the intensity of $\mathrm{OH}$ carboxyl groups and have an impact on increasing the tensile strength of bioplastics.

\section{Bioplastic Characterization}

The amount of bioplastic constituent content will affect the quality of the bioplastics produced. This is due to the ability of the atoms of the bioplastic constituent molecules to bind to one another. The mechanical characteristics of a bioplastic consist of tensile strength, elongation and modulus of young. These parameters can explain how the mechanical characteristics of bioplastics are related to their chemical structure (Akbar, et al., 2013). The results of the physical and mechanical properties of the bioplastics carried out are shown in Table 1 as follows.

Table 1. Results of the physical and mechanical properties of the bioplastics.

\begin{tabular}{ccccc}
\hline $\begin{array}{c}\text { Variation of } \\
\text { CMC } \\
\text { (gram) }\end{array}$ & $\begin{array}{c}\text { Thickness } \\
(\mathrm{mm})\end{array}$ & $\begin{array}{c}\text { Tensile Strenght } \\
(\mathrm{MPa})\end{array}$ & $\begin{array}{c}\text { Elongation } \\
(\%)\end{array}$ & $\begin{array}{c}\text { Modulus Young } \\
(\mathrm{MPa})\end{array}$ \\
\hline 0 & 0,0670 & 8,8433 & 11,8782 & 74,4498 \\
0,25 & 0,0560 & 11,6781 & 7,5187 & 155,3207 \\
0,5 & 0,0630 & 10,2475 & 12,8533 & 79,7266 \\
0,75 & 0,0600 & 19,9235 & 3,5722 & 557,7375 \\
1 & 0,0630 & 12,9742 & 3,2199 & 402,9380 \\
1,25 & 0,0670 & 21,2232 & 3,2922 & 644,6510 \\
1,5 & 0,0620 & 15,9580 & 3,3008 & 483,4586 \\
2 & 0,0795 & 27,5345 & 3,1089 & 885,6670 \\
\hline
\end{tabular}

Based on the graph in Table 1 the relationship between bioplasticthickness $(\mathrm{mm})$ versus variation in CMC addition can be explained which can explain the increase in thickness of bioplastics every additional CMC concentration. Said by Hufail (2012), CMC is a hygroscopic material, so that the more concentration of CMC is added, the water in the material will be more absorbed and bound, the hydroxyl groups in the CMC are able to bind water free of solution, emulsion, or suspension as hydrate water so that when added to the solution, the emulsion or suspension will become thick, thereby affecting the thickness of the bioplastic. So, the more concentrations of CMC added will tend to increase the thickness of the bioplastics. The results of bioplastic thickness analysis in Table 1 show bioplastic thickness values that vary from the addition of CMC. In addition to the volume of material solution, the bioplastic molding process on the printing plate also influences the thickness value. The resulting thickness value is due to the uneven pouring of the solution when printing, the sloping plate position when pouring, so that the bioplastic solution will gather at one point and produce a non-uniform thickness of bioplastics in one bioplastic sheet. According to JIS (Japanese Industrial Standard), bioplastic thickness is said to be standard if it has a thickness of $\leq 0.25 \mathrm{~mm}$. Bioplastic thickness with the addition of CMC on average is below $0.25 \mathrm{~mm}$, so it can be said that the bioplastic has met the standard The addition of CMC variations causes the tensile strength of bioplastics to increase. Based on several previous researchers also stated the same effect, namely Hidayat et al (2013) stated that bioplastics with the addition of CMC will increase the tensile strength of bioplastics, because of the hydrogen bonds that occur between hydroxyl $(\mathrm{OH})$ and carboxyl $(\mathrm{COOH})$ groups of CMC. The hydrogen bonding causes the material strength to increase so that the addition of CMC is proven to increase the tensile strength of bioplastics. Sari (2019) in his research stated that the addition of CMC to a bioplastic solution caused an increase in viscosity of the solution. This is because CMC in solution tends to form crosslinking of polymer molecules. Cross bonds can 
form molecular structures that are rigid and resistant to pressure and increase the tensile strength of bioplastics. The tensile strength standard of bioplastics based on the Indonesian National Standard is 24.7-302 MPa. Tensile strength testing on bioplastics with the addition of CMC variations has tensile strengths ranging from 8.8433 to 27.5345 $\mathrm{MPa}$. When viewed from the existing tensile strength values, the bioplastics that meet SNI standards are bioplastics with variations in the addition of 2 gram CMC.

Based on Table 1 it can be seen that the elongation value is inversely proportional to the tensile strength in the variation of $\mathrm{CMC}$ addition. As the addition of CMC variations the elongation percent value decreases, this is because the combination of starch and CMC which both contain a lot of hydroxyl groups $(\mathrm{OH})$ which causes hydrogen bonds to increase thereby increasing intramolecular forces between chains, causing the flexibility of bioplastics to decrease (Syaubari, et al., 2015). Based on the graph, it can be said that as CMC variations increase, the percent elongation value from bioplastics will decrease. Based on the Indonesian National Standard (SNI), bioplastics with variations in the addition of $\mathrm{CMC}$ as a whole have an average percentage of elongation that still does not meet established standards.

Based on the graph in Table 1 it is known that with the addition of CMC variations, the modulus of young in bioplastics is increasing. This is caused by the addition of CMC variations the value of the stiffness of bioplastics increases. The increased stiffness value of bioplastics is caused by the increased material strength of bioplastics due to the hydrogen bonding that occurs between the hydroxyl $(\mathrm{OH})$ group of starch and hydroxyl $(\mathrm{OH})$ and carboxyl $(\mathrm{COOH})$ groups of $\mathrm{CMCs}$ that bind to each other (Hidayat et al, 2013).

\section{Analisys of Bioplastic functional group}

Synthesized bioplastics were carried out chemical characterization using FTIR instruments. The purpose of this characterization is to determine the functional groups contained in bioplastics and also to determine the effect of mixing canna starch, sorbitol and CMC raw materials added to the functional groups produced before and after the degradation test on bioplastics. The results of FTIR analysis spectra can be seen in Figure 2.

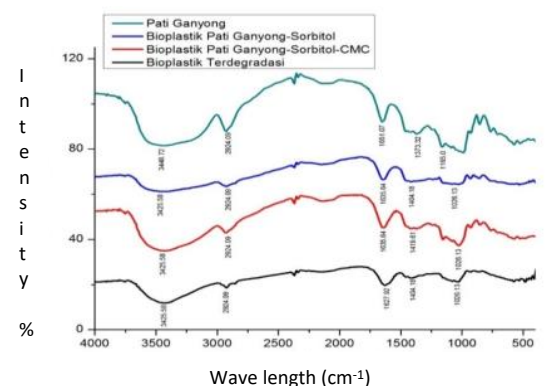

Figure 2. FTIR Spectra of Canna Starch, Canna Starch Bioplastic, Before and After Degradation Bioplastics
Based on Figure 2.spectra of canna starch, it is seen the presence of $\mathrm{OH}$ groups with widening absorption at wave number $3448.72 \mathrm{~cm}^{\wedge}(-1)$. The uptake of the $\mathrm{OH}$ group overlaps with the uptake in the area of $2924.72 \mathrm{~cm}$ $\wedge$ (-1) which is the $\mathrm{C}-\mathrm{H}$ group. The presence of the $\mathrm{CH}_{-}$ group (2) is seen in uptake $1373.32 \mathrm{~cm}^{\wedge}(-1)$. Uptake at a wavelength of $1165 \mathrm{~cm}^{\wedge}(-1)$ indicates the presence of a C-O group.

The FTIR spectra in bioplastic-sorbitol are slightly different from canna starch. The existence of $\mathrm{OH}$ groups is characterized by the absorption of a slightly shifted at wave number $3425.58 \mathrm{~cm}^{\wedge}(-1)$. The existence of $\mathrm{C}-\mathrm{H}$ groups is evidenced by the absorption of the wave number $2924.72 \mathrm{~cm}^{\wedge}(-1)$. Whereas the presence of $\mathrm{C}$ $\mathrm{O}$ groups is characterized by slightly shifting uptake at wave number $1026.13 \mathrm{~cm}^{\wedge}(-1)$. The $\mathrm{C}=\mathrm{O}$ group is indicated by the absorption of the wave number $1635,64 \mathrm{~cm}^{-1}$.

The spectra of bioplastic-sorbitol added to CMC have absorption groups of functions with wave numbers not much different from the spectra of bioplastics-sorbitol, the presence of $\mathrm{OH}$ groups is evidenced by the absorption of wave numbers 3425.58 which have higher absorption intensities compared to bioplastics before the addition of $\mathrm{CMC}$, this is due to the addition of CMC which causes the intensity of $\mathrm{OH}$ groups to increase. The existence of $\mathrm{C}-\mathrm{H}$ groups is evidenced by the absorption of the wave number $2924.72 \mathrm{~cm}^{\wedge}(-1)$. The peak at wave number $1026.13 \mathrm{~cm}^{\wedge}(-1)$ indicates the presence of $\mathrm{CO}$ groups and the presence of $\mathrm{C}=\mathrm{O}$ groups marked by absorption at wave number $1627.92 \mathrm{~cm} \wedge$ (- 1) with higher absorption intensities compared to bioplastic spectra before addition CMC.

The spectra of bioplastics after degradation on the degrading media showed the same functional groups as the sorbitol bioplastic spectra with the addition of CMC. $\mathrm{OH}$ group is evidenced by the absorption at wave number 3425.58 which has lower absorption intensity compared to bioplastics after the addition of CMC. The $\mathrm{C}-\mathrm{H}$ group is proved by the absorption of the wave number $2924.72 \mathrm{~cm}^{\wedge}(-1)$. The peak at wave number $1026.13 \mathrm{~cm}^{\wedge}(-1)$ indicates the presence of CO groups and the presence of $\mathrm{C}=\mathrm{O}$ groups is indicated by absorption at wave number $1627.92 \mathrm{~cm} \wedge(-1)$ with lower absorption intensities compared to bioplastic spectra after addition CMC.

Based on the FTIR spectra analysis presented in Figure 2, the FTIR spectra of bioplastic-sorbitol before and after the addition of $\mathrm{CMC}$, have the same functional groups as the constituent functional groups namely canna starch, and with the addition of CMC does not indicate the presence of new functional groups, so it can it was concluded that the blending process in bioplastic synthesis occurs physically (Elean, 2018). Bioplastic FTIR spectra after diving into degradation in the degrading media experienced a decrease in intensity and a slight shift in wave numbers. This shows the 
occurrence of chemical decomposition of bioplastic constituent compounds caused by the activity of microorganisms in the degrading media.

The existence of $\mathrm{OH}$ and $\mathrm{C}-\mathrm{O}$ functional groups in bioplastics that have been made, indicates that bioplastics have biodegradability. That is because both $\mathrm{OH}$ groups and $\mathrm{C}-\mathrm{O}$ groups are hydrophilic groups, so that they can bind water molecules originating from the surrounding environment as a result microorganisms can enter the bioplastic matrix and make bioplastics degrade (Elean, 2018).

\section{Spearman Correlation Test}

The mechanical properties of the bioplastics produced were then tested by the Spearman correlation to determine the significance of the relationship of variations in the addition of CMC with thickness, tensile strength, elongation and modulus of young from bioplastics.The results of the Spearman correlation test with the mechanical properties of bioplastics are presented in Table 2.

Table 2. Results of the Spearman correlation test with the mechanical properties of bioplastics.

\begin{tabular}{|c|c|c|c|c|c|c|c|}
\hline & & & Variation & Thickness & $\begin{array}{l}\text { Tensile } \\
\text { Strength }\end{array}$ & Elongation & $\begin{array}{l}\text { Modulus } \\
\text { Young }\end{array}$ \\
\hline \multirow[t]{3}{*}{ Spearman's rho } & \multirow[t]{3}{*}{ Variation } & Correlation Coefficient & 1.000 & .349 & $.857(* *)$ & $-.833(*)$ & $.857(* *)$ \\
\hline & & $\begin{array}{l}\text { Sig. } \\
\text { (2-tailed) }\end{array}$ & . & .396 & .007 & .010 & .007 \\
\hline & & $\mathrm{N}$ & 8 & 8 & 8 & 8 & 8 \\
\hline
\end{tabular}

Based on the results of the spearman correlation test, Table 2 is then interpreted by matching the correlation coefficient values obtained with the correlation coefficient values in Table 3 . It appears that the relationship of adding CMC variations to bioplastic thickness has a spearman correlation value of 0.349 with a significance value of 0.396 . This shows that the relationship of variations in the addition of $\mathrm{CMC}$ to thickness is weak. This means that the addition of CMC variations does not greatly affect the thickness value of bioplastics.

Meanwhile, the spearman correlation value generated between variations in the addition of CMC to the tensile strength of bioplastics is 0.857 with a significance value of 0.007 . This means that the addition of CMC variations has a very strong relationship to the value of bioplastic tensile strength. The greater the concentration variation of the added CMC, it will increase the tensile strength significantly. Spearman correlation value between the variation of CMC concentrations to the percent elongation of bioplastics is negative 0.833 with a significance value of 0.010 . This shows that the addition of variations in the concentration of CMC has a very strong relationship to the value of bioplastic elongation produced. The greater the concentration of CMC added, the lower the elongation of bioplastics. Spearman correlation value between variations with modulus young value is 0.857 with a significance value of 0.007 . From these data it can be concluded that the addition of CMC variations has a very strong relationship to the value of the young modulus produced. Overall it can be said that the addition of CMC to thickness has a weak relationship, whereas the tensile strength, elongation and modulus of young, has a very strong relationship to the variation of $\mathrm{CMC}$ added.
Table 3. Relationship Level of Two Variables (Qudratullah, 2014).

\begin{tabular}{ll}
\hline CoefisienKorelation & Relationship Level \\
\hline 1 & Sempurna \\
$0,75-0,99$ & Very Strong \\
$0,50-0,74$ & Strong \\
$0,25-0,49$ & Weak \\
$0,01-0,24$ & Very Weak \\
0 & No \\
\hline
\end{tabular}

\section{Biodegradation Test}

Figure 3 shows the percentage reduction in the mass of a bioplastic sample with the addition of CMC variations after a soil burial test was performed for 21 days. Based on the graph, it can be seen that bioplastics with the addition of CMC variations made have Biodegradable properties. This is evidenced by the increasingly reduced mass of bioplastics during the biodegradation testing process on soil media. The percentage of weight loss which tends to be greater indicates that the sample is degraded faster. Bioplastic biodegradation capability increases with the increase in the amount of CMC added. $\mathrm{CMC}$ itself is a stabilizer that can form colloids in water. The colloidal nature of CMC functions as a stabilizer or can stabilize suspense. The more concentrations of CMC added cause more water to be absorbed and bound, which results from CMC being hygroscopic (Rahayu, 2016). Because of its hygroscopic nature, bioplastics with the addition of CMC have high humidity, high humidity levels are a good habitat for microbes to degrade bioplastics (Hardjono et al, 2016). Thus the ability of biodegradation tends to increase with increasing levels of CMC added. 

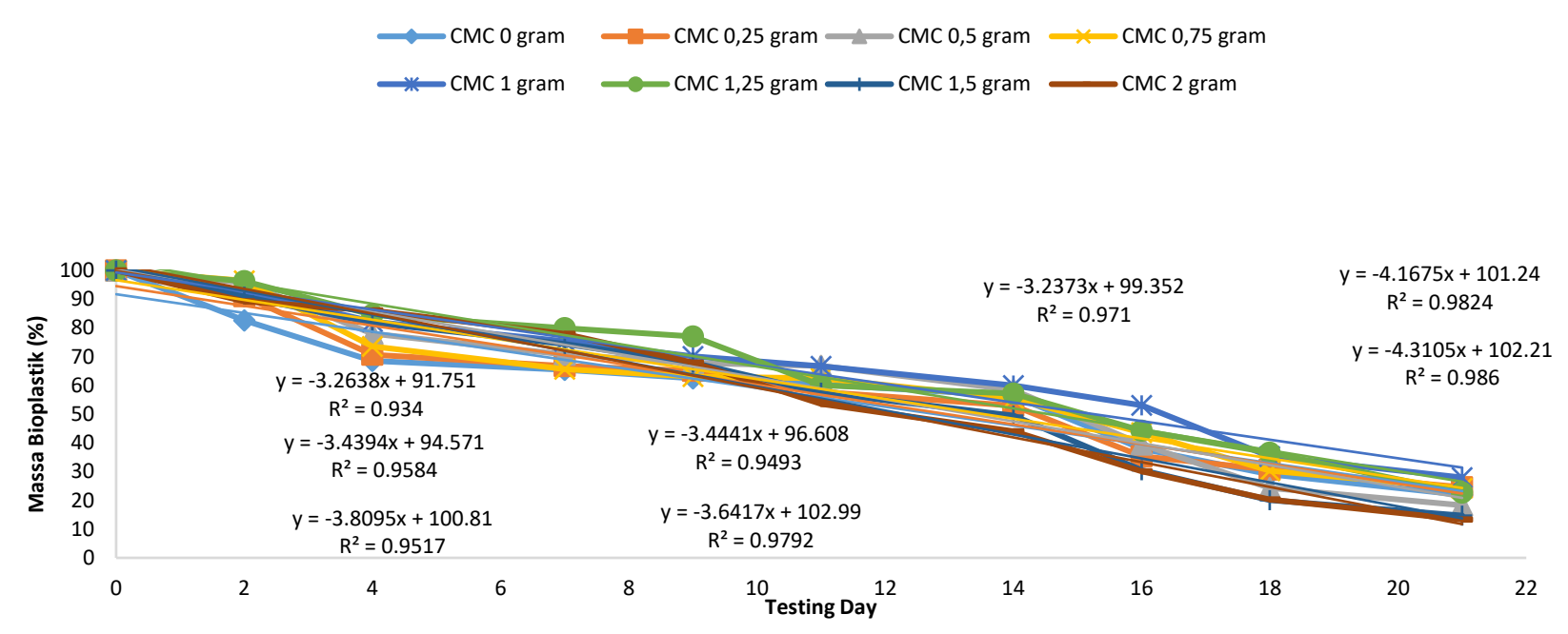

Figure 3. CMC Bioplastic Biodegradation Graph in Soil Media.

Table 4. Analysis of Biodegradation Variations in Soil Media.

\begin{tabular}{lllllllllll}
\hline & Day 0 & Day 2 & Day 4 & Day 7 & Day 9 & Day 11 & Day 14 & Day 16 & Day 18 & Day 21 \\
\hline Chi-Square & 0.000 & 17.947 & 18.440 & 10.547 & 5.640 & 7.387 & 12.347 & 12.547 & 8.093 & 10.733 \\
Df & 7 & 7 & 7 & 7 & 7 & 7 & 7 & 7 & 7 & 7 \\
Signification & 1.000 & .012 & .010 & .160 & .582 & .390 & .090 & .084 & .324 & .151 \\
\hline
\end{tabular}

The effect of the addition of variations in CMC concentrations on the bioplastic degradation properties was further analyzed using the Kruskal-Wallis statistical method which aims to determine the significance of the differences produced by each measurement of biodegradation test on the second day to the twenty-first day. The results of the analysis can be seen in Table 4 .

Based on Table 4, it is known that the results of the analysis of variance that have been done show that there are significant differences that occur on the second day and the fourth day, because the significance number on the second day is 0.012 and on the fourth day is 0.01 , both of which are still below 0.05 . This means that the addition of CMC variations significantly affect the decrease in bioplastic mass on the second and fourth day. Whereas on the seventh, ninth, eleventh, fourteenth, sixteenth, eighteenth, and twenty-first days the biodegradation test showed a significance level of more than 0.05. This means that the results of the analysis of variance do not show any significant differences. This means that variations in CMC variations do not significantly affect bioplastic mass reduction. From the results of the above analysis as a whole it can be seen that the effect of the addition of CMC is seen to significantly only occur on the second and fourth days, whereas on other days, it does not significantly affect the decrease in bioplastic mass in the soil media.

\section{Best Biodegradable FTIR Plastic Test with CMC Addition}

Characterization of biodegradable plastic is carried out using FTIR. Analysis using FTIR aims to determine the functional groups contained in biodegradable plastic. Biodegradable plastic with the addition of CMC peak appearance in the wave number area $2916.26 \mathrm{~cm}-1$, which indicates the presence of $\mathrm{CH}$ group, uptake 1461.94 indicates the presence of $\mathrm{CH} 2$ groups. At wave numbers 1014, $48 \mathrm{~cm}-1,1076.20 \mathrm{~cm}-1,1103.20 \mathrm{~cm}-1$, and $1149.49 \mathrm{~cm}-1$ indicate the presence of $\mathrm{C}-\mathrm{O}$ ether. Based on the picture above, the spectrum of biodegradable plastic with the addition of $\mathrm{CMC}$ shows that there are $\mathrm{CH}, \mathrm{CH} 2$ and $\mathrm{CO}$.

\section{CONCLUSION}

Bioplastic biodegradation tests conducted using soil media have decreased mass from the first day of observation to the twenty-first day. The addition of CMC variations tends to increase the degrability of bioplastics.

\section{REFERENCES}

Akbar, Fauzi., Anita, Zulisma., dan Harahap, Hamidah. 2013. Pengaruh Waktu Simpan Film Plastik Biodegradasi Dari Kulit 
Singkong Terhadap Sifat Mekanikalnya. Jurnal Teknik Kimia USU, Vol.2, No. 2.

Anas, Argo Khoirul; Salma, Atika; Nugroho, Firman; Linguistika, Yulia dan Filinoristi, Winny. 2012. PengaruhVariasi Massa Umbi Ganyong (Canna edulis Kerr) pada pembuatan dan Karakterisasi Plastik Biodegradable Ramah Lingkungan Berbahan Dasar Umbi Ganyong. Prosiding Seminar Nasional Penelitian, Pendidikan dan Penerapan MIPA, Fakultas MIPA Uiversitas Negeri Yogyakarta.

Darni, YulidanUtami, Herti. 2010. Studi Pembuatan dan Karakterisasi Sifat Mekanik dan Hidrofibitas Bioplastik dari Pati Sorgum. Jurnal Rekayasa Kimia dan Lingkungan, Vol. 7, No. 4: $88-93$.

Elean, Samuel.,Saleh, Chairul., dan Hindryawati, Noor. 2018. Pembuatan Film Biodegradable Dari Pati Biji Cempedak dan Carboxy Methyl Cellulose Dengan Penambahan Gliserol. Jurnal Atomik Vol. 3 No. 2. Hal.122-126.

Ghanbarzadeh, Babakdan Almasi, Hadi. 2010. Biodegradable Polymers. University of Tabriz Press Chapter 6 No. 146.

Hardjono, Suharti, Profiyanti Hermien, Permatasari, Dita Ayu, dan Sari, Vivi Alvionita. 2016. Pengaruh Penambahan Asam Sitrat Terhadap Karakteristik Film Plastik Biodegradable dari Pati Kulit Pisang Kepok (Musa Acuminata Balbisiana Colla). Jurnal Bahan Alam terbarukan JBAT 5(1) hal 22-28.

Harmayani, Eni; Murdiyati, Agnes, dan Griyaningsih.2011. Karakterisasi Pati Ganyong (Canna edulis) dan Pemanfaatanya Sebagai Bahan Pembuatan Cookies dan Cendol. AGRITECH, Vol. 31. No. 34.

Hasanah, Yeti Resmiati.; Khasanah, UmiUswatun.; Wibiana, Endang; dan Haryanto. 2016. Pengaruh Penambhan CMC (Carboxy Methyl Cellulose) Terhadap Tingkat Degrabilitas Dan Struktur Permukaan Plastik Ramah Lingkungan. Jurnal Teknik Kimia Universitas Muhammadiyah Purwokerto.

Hidayat, M. Khoirul.; Latifah; dan Sedyawati, Sri M. R. 2013. Penggunaan Carboxy Methyl Cellulose Dan Gliserol Pada Pembuatan Plastik Biodegradable. Indonesian Journal of Chemical Science.Sci 2.
Hidayati, S., A.S. Zuidar, dan A. Ardani. 2015. Aplikasi Sorbitol pada Produksi Biodegradable Film dari Nata de Cassava. $J$. Reaktor, Vol. 15, No, 3.

Hufail, Ibnu, hasnelly, taufik, Yusman. 2012. Artikel Pengaruh Konsentrasi Carboxymetil Cellulose (CMC) dan Gliserol terhadap karakteristik Edible Film Bekatul Padi (Oryza sativa). Bandung: Universitas Pasundan.

Khalistyawati, Shinta; Kristijanto, Agustinus Ignatius; Hartini, Sri.2016. Optimasi Bioplastik kelobot Jagung (zea mays L, Ditinjau dari Nisbah Biokomposit, penambahan ZnO Dan Plasticizer Gliserol. Prosiding Seminar Nasional Sains dan Enterpreneurship III Tahun 2016. Jurnal Sains Terapan No. 516-521.

Kusnandar, Feri. 2010. Kimia Pangan Komponen Makro. Jakarta: Dian Rakyat.

Novela, Inka, Amri, Idral, HS Irdoni. 2018. Karakteristik Bioplastik dari Komposit Limbah Cair Tahu (Whey) Dan Serat Daun Nanas (Ananascomosus) Dengan Hidrokoloid Carboxy Methyl Cellulose (CMC). Jurnal Jom FTEKNIK Volume 5 .

Quadratullah, Muhammad Farhan. 2014. Statistika Terapan Teori, Contoh Kasus, dan Aplikasi dengan SPSS. Yogyakarta: Penerbit Andi.

Rahayu, Astria Pangesti. 2016. Kajian Karakteristik Edible Film Pati Hanjeli (Coixlacyma-jobi L.) Dengan Pengaruh Konsentrasi Pemlastis Sorbitol Dan Konsentrasi Penstabil CMC. Jurnal Teknologi Pangan Universitas Pasundan Bandung.

Sharma, Manika, Pratibta Sharma, Anima Sharma dan Subash Chandra. 2015. Microbial Degradation of Plastic-A Brief Review. CIBTech Journal of Microbiology Vol. 4 No. 1:85-89.

Syaubari., Reza, Medyan., Rosnelly, Cut Meurah., dan Irmayanti. 2015. Karakterisasi Plastik Biodegradable Dari Pati Bonggol Pisang dan CMC (Carboxy Methyl Cellulose) Dengan Penambahan Anti Oksidan. Prosiding Seminar Nasional Hasil Riset dan Standarisasi Industri V tahun 2015. 
THIS PAGE INTENTIONALLY LEFT BLANK 